\title{
Firms' exporting and importing activities: is there a two-way relationship?
}

\author{
David Aristei* \\ Davide Castellani ${ }^{\dagger}$ \\ Chiara Franco
}

May 25, 2012

\begin{abstract}
The literature on firm heterogeneity and trade has highlighted that most trading firms tend to engage in both importing and exporting activities. This paper provides some evidence that helps understanding to what extent this is the result of a two-way relationship. Using firm-level data for a group of 27 Eastern European and Central Asian countries from the World Bank Business Environment and Enterprise Performance Survey (BEEPS) over the period 2002-2008, we estimate a bivariate probit model of exporting and importing. After controlling for size (and other firm-level characteristics) we find that firms' exporting activity does not increase the probability of importing, while the latter has a positive effect on foreign sales. This effect is mainly channeled through an increase in firm productivity and product innovation.
\end{abstract}

Keywords: Export, Import, Firm heterogeneity, Eastern European and Central Asian countries

JEL Classification: F14; F21; F23.

\footnotetext{
*Department of Economics, Finance and Statistics, University of Perugia, david.aristei@stat.unipg.it

$\dagger$ Department of Economics, Finance and Statistics, University of Perugia, davide.castellani@unipg.it

${ }^{\ddagger}$ Department of Economics, University of Bologna; e-mail: chiara.franco2@unibo.it
} 


\section{Introduction}

The recent empirical international trade literature has highlighted that a high proportion of trading firms is engaged in both importing and exporting activities $^{1}$. The emergence of these two-way traders may have different explanations. First, assuming that both exporting and importing activities bear sunk costs, the most productive firms will self-select into two-way trade (Kasahara and Lapham, 2008). Second, to the extent that the same sunk costs are at least partially shared by exporting and importing activities, the cost of exporting (importing) decreases whenever firms already carry out importing (exporting) activities, and this increases the probability to become a two-way trader, once a firm is already a one-way trader (Kasahara and Lapham, 2008). Third, importing (exporting) may actually have an effect on exporting (importing), either because they open up new information channels or through increases in productivity and innovation (Kasahara and Lapham, 2008; Kugler and Verhoogen, 2009; Lileeva and Trefler, 2010; Verhoogen, 2008; Salomon and Shaver, 2005; Bustos, 2011)2.

While considerable empirical research has addressed the links between either exporting or importing activity and firms' productivity and innovation, only limited evidence has been provided on the two-way relationship between importing and exporting activities. In this paper, we empirically investigate this two-way link with reference to a sample of 1,085 firms from 27 Eastern European and Central Asian (ECA) countries from the World Bank Business Environment and Enterprise Performance Survey (BEEPS) over the period 2002-2008. These countries are particularly interesting for the purpose of our analysis, since they underwent the transition from central planning to the market economy. Starting from the $90 \mathrm{~s}$, this process has forced most firms in these countries to upgrade previously adopted technologies and improve product quality and productivity. Among other institutional reforms, trade liberalization has allowed access to foreign technologies and integration into the world economy (especially with the European Union), has favoured the convergence with the more advanced economies and stimulated an increase in the quality and variety of exported goods (Benkovskis and Rimgailaite, 2011; Zaghini, 2005).

We estimate a bivariate probit model of the probability of firms' exporting and importing finding that there is indeed a positive two-way correlation between import and export but, after controlling for size, productivity and other firm-

\footnotetext{
${ }^{1}$ Evidence of this pattern has been provided for countries as different as Belgium (Muûls and Pisu, 2009), Chile (Kasahara and Lapham, 2008), Denmark (Smeets and Warzynski, 2010), Germany (Vogel and Wagner, 2010), Hungary (Altomonte and Bekes, 2010), Italy (Castellani, Serti, and Tomasi, 2010) and the United Stated (Bernard, Jensen, and Schott, 2009 ).

${ }^{2} \mathrm{~A}$ spurious correlation between importing and exporting may also result from the fact that financially constrained firms may first engage in the less costly option, and then subsequently resort to relatively more costly internationalization. Furthermore, since importing is somewhat technically constrained, firms may be forced to engage in foreign sourcing, and, possibily, later they would start serving foreign markets.
} 
level characteristics, past exporting does not increase the current probability of sourcing inputs from abroad, while past importing activities have a positive effect on the current probability of selling into foreign markets. However, this latter effect disappears once we control for current productivity and the propensity to introduce product innovation. This is consistent with the idea that importing contributes to increase firm productivity and product innovation, which in turn foster exporting activity.

The rest of the paper is organized as follows. Section 2 discusses the related literature. Section 3 presents the sample and data used for the empirical analysis, while Section 4 lays out our econometric methodology, specification and results. Section 5 reports some robustness checks. Section 6 concludes the paper.

\section{Related literature}

In this section we review the main theoretical and empirical contributions which can help explain why firms engage in two-way trade. In particular, Section 2.1 discusses the role of self-selection and sunk-cost complementarity, Section 2.2 and 2.3 illustrate the theory and evidence on the link between import and export (respectively) with productivity and innovation, while Section 2.4 reports the scarse evidence on the import-export nexus. Finally, Section 2.5 reviews the relevant empirical evidence on Transition economies.

\subsection{Self-selection and sunk cost complementarity}

Kasahara and Lapham (2008) extend the Melitz (2003) model incorporating the possibility that firms engage in intermediate goods import. The model includes both sunk costs of initiating export $\left(c_{x}\left(1-d_{i t-1}^{x}\right)\right)$ and import $\left(c_{m}(1-\right.$ $\left.\left.d_{i t-1}^{m}\right)\right)^{3}$. In this setting, firms that engage in both importing and exporting activities need to bear higher sunk costs, thus only the most productive firms will self-select into two-way trade. However, if the sunk costs were (at least partially) common to exporting and importing activities ${ }^{4}$, for a given productivity level, firms already engaged in one-way trade would be more likely to become two-way traders. Kasahara and Lapham (2008) assume that the cost of carrying out both importing and exporting activities activities is $\zeta\left[c_{x}\left(1-d_{i t-1}^{x}\right)+c_{m}\left(1-d_{i t-1}^{m}\right)\right]$, with the cost complementarity parameter $\zeta<1$. They estimate the parameter $\zeta$

\footnotetext{
${ }^{3}$ The model includes also per period fixed costs of importing and exporting and a start-up cost, which we omit for the sake of simplicity. $d_{i t-1}^{x}$ and $d_{i t-1}^{m}$ are indicators which take value 1 if a firm was exporting or importing at t- 1 .

${ }^{4}$ For example, one may think that the organizational structure needed to manage exporting activities can at least partially be used to manage international purchase of intermediate goods (e.g. the import-export office), or that when firms acquire information on a foreign market, these can be used both when deciding to serve that market, or when sourcing intermediate inputs from that market.
} 
for Chilean firms, and find that it is significantly lower than one (ranging from .746 in the Wood industry, to .930 in Food).

\subsection{Importing, productivity and innovation}

Importing intermediate inputs may pave the way to future exporting via an increase in productivity and/or product innovation. If a firm resorts to foreign as well to domestic sourcing, it can have access to higher quality intermediate inputs, benefit from a higher variety of inputs, and maximize the complementarity between foreign and domestic ones. Using a sample of Hungarian firms, Halpern, Koren, and Szeidl (2009) find that two-third of productivity gains from importing is due to the variety and complementarity effects, and one-third to the higher quality of foreign sourced inputs. A positive link between firm productivity and foreign sourcing has been provided in the case of Belgium (Muûls and Pisu, 2009), Chile (Kasahara and Rodrigue, 2008), Germany (Vogel and Wagner, 2010), Ireland (Forlani, 2011) Italy (Castellani, Serti, and Tomasi, 2010; Conti, Lo Turco, and Maggioni, 2011), Spain (Augier, Cadot, and Dovis, 2010; Farinas and Martin-Marcos, 2010), Sweden (Andersson, Loof, and Johansson, 2008; Loof and Andersson, 2010) and the US (Bernard, Jensen, and Schott, 2009), while Amiti and Konings (2007) showed that the reduction in intermediate inputs tariff had a significant effect on Indonesian firms' productivity. A complementary stream of research has also found evidence that imported intermediates increase product innovation, in terms of higher quality (Kugler and Verhoogen, 2009) and larger product scope (Goldberg, Khandelwal, Pavcnik, and Topalova, 2010; Colantone and Crinò, 2011).

\subsection{Exporting, productivity and innovation}

Most studies on export and productivity find sound evidence of a self-selection effect, that is future exporters are ex-ante more productive, while evidence on the productivity-enhancing effects of exporting activity ('learning-by-exporting') is mixed (Wagner, 2007). Earlier studies found no such effects in countries as different as Colombia (Clerides, Lach, and Tybout, 1998) and the United States (Bernard and Jensen, 1999), and these results were later confirmed for a larger number of both developed and developing countries (ISGEP, 2008). However, other studies have found evidence of positive effects of exporting on firm productivity in Canada (Lileeva and Trefler, 2010), Chile (Alvarez and López, 2005), China (Park, Yang, Shi, and Jiang, 2010), Indonesia (Blalock and Gertler, 2004), Italy (Serti and Tomasi, 2008), sub-Saharan Africa (Van Biesebroeck, 2005), UK (Girma, Greenaway, and Kneller, 2004). Lileeva and Trefler (2010) showed that these gains were more significant for firms whose initial productivity was relatively 
lower and for old exporters. The latter result is consistent with some evidence on China, Italy and Sweden where higher productivity growth is associated with a higher share export on total sales (Kraay, 1999; Castellani, 2002; Andersson and Loof, 2009).

A related strand of research has investigated how exporting activity is related to innovation. Most studies support the hypothesis that firms that start to sell into foreign markets are ex-ante more innovative (e.g. Sterlacchini, 1999; Basile, 2001; Roper and Love, 2002; Cassiman, Golovko, and Martínez-Ros, 2010; Caldera, 2010), while only a few papers convincingly show evidence that exporting activity spurs product innovation (also in the form of improved product quality) or process innovation (also through the adoption of newer technologies) (Lileeva and Trefler, 2010; Salomon and Shaver, 2005; Bratti and Felice, 2011). In particular, Lileeva and Trefler (2010) find that Canadian exporters that improved productivity were more likely to introduce new product innovation and advanced manufacturing as well as inspection and communication technologies. Consistent with these results, Bustos (2011) finds that Argentinian firms in industries facing higher reductions in Brazil's tariffs increase investment in technology faster.

\subsection{Evidence on the import-export nexus at the firm-level}

Despite the considerable theoretical and empirical literature on the import (export) and productivity/innovation nexus, we are aware of only the studies of Muûls and Pisu (2009) and Kasahara and Lapham (2008) on the two-way relationship between importing and exporting activities. Using data on a sample of 19,178 Belgian firms over the period 1996-2004, Mûhls and Pisu (2009) estimate a dynamic panel probit for both the probability of exporting (importing), as a function of the importing (exporting) status in the previous year. They find that previous trade status is significant in both the import and export equation, and the effect of importing (exporting) on exporting (importing) is similar in magnitude. As anticipated in section 2.1. Kasahara and Lapham (2008) build a structural model of self-selection into exporting and importing and test it on a sample of Chilean plants in 6 manufacturing industries over the period 1990-1996. After controlling for firm characteristics they find a lower frequency of exporters among non-importers than among importers and use this to identify the cost complementarity parameter $\zeta$. According to their estimates, $\zeta$ is significantly lower than one and ranges from .746 in the Wood industry to .930 in Food.

A couple of more recent studies address one way of the import-export nexus, that is the effect of imported intermediates on firms' exporting activies. Using firm-level data on imports at the product (HS6) level Bas and Strauss-Kahn (2010) find that a higher diversification and increased number of imported varieties affect export scope, mainly through complementarity and technology transfer mechanism. Instead, Lo Turco and Maggioni (2011) show some evidence of a price effect in Italy. In particular, a higher share of imports from low-income 
countries, which they assume are motivated by the desire to lower costs, have positive effect on the propensity to export of Italian firms, while import from high-income countries have no effect.

\subsection{Importing, exporting, productivity and innovation in Transition economies}

Transition economies have attracted a certain number of works which, from a macroeconomic point of view, highlight the role of exports and import as engines of growth (Bajo-Rubio and Díaz-Roldán, 2012; Awokuse, 2007). Cetintas and Barisik (2009), estimate a multivariate auto-correction model on quarterly data from 1995 to 2006 for 13 transition economies and find evidence of a two-way causality between import and exports.

At a more microeconometric level the focus has been on the effect of imports and exports on firms' productivity, while, to the best of our knowledge, evidence is lacking on the the two-way relationship between importing and exporting activity at the level of the firm. Analyzing the exporting activity of Russian firms towards developed countries, Wilhelmsson and Kozlov (2007) find inconclusive evidence of learning-by-exporting, while De Loecker (2007), using data from Slovenia, finds a positive causal effect of firms' exporting activities on their productivity. Damijan and Kostevc (2006) qualify this result, noticing that gains in productivity are larger immediately after the entry into the export market but they tend to vanish quite rapidly. More general results are provided by Damijan, de Sousa, and Lamotte (2009) for six transition countries in South-Eastern-Europe (Bosnia-Herzegovina, Bulgaria, Croatia, Macedonia, Romania and Slovenia). They find that the importing and exporting activities have positive effects on firm productivity in four out of six countries, but these results depend on the destination/origin markets, since trading with advanced countries has a larger impact on productivity. Finally, using an extended version of the dataset used in this paper - including 43 developing countries and not only ECA countries - Seker (2009) show that two-way traders are the fastest growing and most innovative group and argues that failing to control for the import status may lead to overestimate the productivity premium of exporters.

In sum, the existing theoretical and empirical evidence suggests that only the most productive firms should engage in two-way trade, and that - in the presence of sunk cost complementarity - after controlling for firm characteristics, importers would be more likely to start exporting (and viceversa). The literature highlights that the two-way link between importing and exporting is most likely channeled through an increase in productivity and product innovation. On this regards, evidence on the export-productivity/innovation nexus is mixed, while more robust results have been found on the causal effect of importing intermedi- 
ates on firm productivity and product scope/innovation. Consistently with this mechanism, an indirect causal link between import, GDP and exports have been found at the macro-economic level for 13 Transition economies. This paper will provide new firm-level evidence along the same lines.

\section{Data}

We exploit firm-level data from the Business Environment and Enterprise Performance Survey (BEEPS), jointly conducted by the World Bank and the European Bank for Reconstruction and Development on firms from Eastern European and Central Asian (ECA) countries in 2002, 2005 and 2008 . The BEEP Surveys use standardized instruments and a uniform sampling methodology to collect comparable data both across countries and over time on a sample of firms in the manufacturing and retail/wholesale industries, representative of each country's private non-agricultural economy. The main aims of the BEEPS are to assess the environment for private enterprise and business development, focusing primarily on business-government relations, infrastructure, financial markets and credit access, degree of competition, crime and corruption, and to analyse the performance of firms in terms of sales, productivity, innovation activities and international operations. From 2002, a fraction of firms are re-interviewed across multiple years thus allowing to obtain a panel component, which makes it possible to track changes in business environment and firm behaviour over time.

For the purpose of this analysis, we focus on manufacturing firms from 27 ECA countries observed for the period 2002-2008 ${ }^{6}$. As we will show in Section 4. our econometric specification requires that for each firm we have information on current and past indicators of exporting and importing activity, as well as on predetermined firm-characteristics. For this reason, we refer to the panel component of the BEEPS using information on firms that were interviewed at least in two consecutive waves over the period of analysis ${ }^{7}$. This significantly reduces the number of usable observations, as all firms that are surveyed only once have to be dropped.

As documented by Table 1 we end up using 1,085 observations, out of which 714 refer to current import and export status in 2008 (for which explanatory variables, including lagged import and export status, refer to 2005) and 371 refer to the 2005 survey for the dependent variables (and to the 2002 survey for

\footnotetext{
${ }^{5}$ The BEEPS is currently a component of the broader World Bank Enterprise Survey project. Cross-sectional and longitudinal datasets and all the relevant survey documentation are publicly available at www.enterprisesurveys.org.

${ }^{6}$ We chose to exclude Turkey, which had a far larger number of observations than the other countries, so that results would have been too much dependent on this country

${ }^{7}$ We use the latest the BEEPS Panel dataset release available at the time of writing (version as of April 30, 2010).
} 
the regressors) ${ }^{8}$. We will treat the data as two independent cross-sections (one referred to the 2002-2005 period and the other to 2005-2008), even if it should be said that 110 firms appear in both the sub-samples ${ }^{9}$.

In Tables A.1 and A.3 in the Appendix, we present the sample composition and some descriptive statistics to compare firms in the estimation sample to the original BEEPS data. From the analysis of the Tables, it is possible to point out that the country composition and firm characteristics of our estimation sample are very similar to those of the original BEEPS panel database. With respect to the original pooled cross-sections data, which includes information on firms surveyed only for one year that cannot be used in the estimation, we have a slight over-representation of large and medium sized firms, as well as of state- and foreign-owned firms. This comparison reassures us that we are not introducing any significant selection bias.

Table 1 reveals that one-fourth of the firms do not trade, and only $6.1 \%$ are engaged only in exporting activities. Two-way traders and firms sourcing foreign inputs (but serving only the domestic market) are both around one-third of the sample. Table 2 shows that the propensity to engage in either or both exporting and importing activities differs across countries. In particular, in some of the relatively more advanced (and integrated within the European Union) countries, such as Czech Republic, Estonia, Hungary, Latvia, Lithuania, Serbia, Slovakia and Slovenia, the share of two-way traders is sensibly higher. In the econometric analysis we will take this issue into account by way of country fixed effects.

Table 1: Sample composition, by year and trade status

\begin{tabular}{lcccccc}
\hline Year & Total & $\begin{array}{c}\text { Non } \\
\text { Traders }\end{array}$ & $\begin{array}{c}\text { Export } \\
\text {-only }\end{array}$ & $\begin{array}{c}\text { Import } \\
\text {-only }\end{array}$ & $\begin{array}{c}\text { Two-way } \\
\text { traders }\end{array}$ & Total \\
\hline \multicolumn{7}{c}{ abs. \# } \\
\hline 2005 & 371 & 27.4 & 7.2 & 28.5 & 36.6 & 100 \\
2008 & 714 & 25.2 & 5.6 & 37.8 & 31.3 & 100 \\
\hline Total & 1,085 & 25.9 & 6.1 & 34.6 & 33.1 & 100 \\
\hline
\end{tabular}

In Table 3 we address the issue of the firm transition between trade statuses. The highest probability of transition is observed for firms which started out as exporter-only. Only $32.9 \%$ of such firms remain in the same status, as opposed

\footnotetext{
${ }^{8}$ The original sample of manufacturing firms also includes 5,747 firms observed only for one year (3,080 firms in 2008 and 2,667 in 2005) that cannot be used in the empirical application.

${ }^{9}$ These firms are observed in all the three surveys, while 261 are observed in 2005 and 2002, and 604 are observed in 2008 and 2005. In order to account for repeated observations on the same firm over time, in all the empirical models we use standard errors of the estimated parameters clustered by firm.
} 
Table 2: Sample composition, by country and trade status

\begin{tabular}{|c|c|c|c|c|c|c|}
\hline Country & Total & $\begin{array}{c}\text { Non } \\
\text { traders }\end{array}$ & $\begin{array}{c}\text { Export } \\
\text {-only }\end{array}$ & $\begin{array}{l}\text { Import } \\
\text {-only }\end{array}$ & $\begin{array}{c}\text { Two-way } \\
\text { traders }\end{array}$ & Total \\
\hline & abs. \# & \multicolumn{5}{|c|}{ percentage values } \\
\hline Albania & 33 & 18 & 3 & 42 & 36 & 100 \\
\hline Armenia & 67 & 15 & 1 & 54 & 30 & 100 \\
\hline Azerbaijan & 70 & 47 & 4 & 40 & 9 & 100 \\
\hline Belarus & 29 & 10 & 0 & 59 & 31 & 100 \\
\hline Bosnia & 26 & 19 & 4 & 35 & 42 & 100 \\
\hline Bulgaria & 46 & 22 & 9 & 30 & 39 & 100 \\
\hline Croatia & 31 & 10 & 3 & 48 & 39 & 100 \\
\hline Czech Rep. & 16 & 6 & 6 & 25 & 63 & 100 \\
\hline Estonia & 21 & 10 & 5 & 38 & 48 & 100 \\
\hline FYROM & 44 & 11 & 5 & 39 & 45 & 100 \\
\hline Georgia & 31 & 19 & 13 & 26 & 42 & 100 \\
\hline Hungary & 32 & 22 & 6 & 22 & 50 & 100 \\
\hline Kazakhstan & 51 & 55 & 0 & 33 & 12 & 100 \\
\hline Kyrgyz & 37 & 38 & 5 & 32 & 24 & 100 \\
\hline Latvia & 24 & 25 & 13 & 17 & 46 & 100 \\
\hline Lithuania & 24 & 21 & 4 & 21 & 54 & 100 \\
\hline Moldova & 75 & 24 & 11 & 45 & 20 & 100 \\
\hline Montenegro & 2 & 0 & 0 & 100 & 0 & 100 \\
\hline Poland & 44 & 32 & 11 & 27 & 30 & 100 \\
\hline Romania & 74 & 36 & 5 & 42 & 16 & 100 \\
\hline Russia & 22 & 23 & 9 & 45 & 23 & 100 \\
\hline Serbia & 60 & 17 & 8 & 10 & 65 & 100 \\
\hline Slovakia & 17 & 0 & 18 & 6 & 76 & 100 \\
\hline Slovenia & 41 & 5 & 2 & 7 & 85 & 100 \\
\hline Tajikistan & 33 & 33 & 9 & 39 & 18 & 100 \\
\hline Ukraine & 90 & 34 & 7 & 37 & 22 & 100 \\
\hline Uzbekistan & 45 & 44 & 7 & 36 & 13 & 100 \\
\hline Total & 1,085 & 26 & 6 & 35 & 33 & 100 \\
\hline
\end{tabular}


to more than $50 \%$ in the case of firms which at time $t-3$ where non-traders, importer-only or two-way traders. Among exporter-only firms there is a relatively high probability to stop exporting $(20.3 \%$ become non-traders and $15.2 \%$ stop exporting but start importing), but the more likely event is to keep exporting and add importing (31.7\%). However, firms starting out as exporters-only are only 79 out of 1,085 . The number of firms which at time $t-3$ were importersonly is much larger (331), they display a higher rate of persistence and, while it is rather unlikely that these firm stop importing and start exporting (only $3.3 \%$ of the cases), it is equally likely that they either stop importing or add exporting activities. Two-way traders are the most persistent type (67\% of firms remain in this trade status) and if they change status they are more likely to stop exporting rather than importing. Finally, non-traders tend to remain non-internationalized but if they do start trading, they begin by sourcing foreign inputs, rather by selling into foreign markets.

Table 3: Transition matrix across trade status

\begin{tabular}{|c|c|c|c|c|c|c|}
\hline & \multicolumn{5}{|c|}{ Trade status $_{t}$} \\
\hline & & $\begin{array}{c}\text { Non } \\
\text { traders }\end{array}$ & $\begin{array}{l}\text { Export } \\
\text {-only }\end{array}$ & $\begin{array}{l}\text { Import } \\
\text {-only }\end{array}$ & $\begin{array}{c}\text { Two-way } \\
\text { traders }\end{array}$ & Total \\
\hline \multirow{12}{*}{ 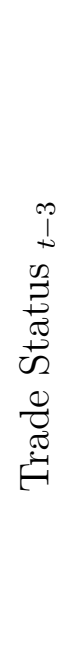 } & & \multicolumn{5}{|c|}{ absolute numbers } \\
\hline & Non trader & 173 & 6 & 103 & 14 & 296 \\
\hline & Exporter-only & 16 & 26 & 12 & 25 & 79 \\
\hline & Importer-only & 65 & 11 & 188 & 67 & 331 \\
\hline & Two-way trader & 28 & 24 & 73 & 254 & 379 \\
\hline & Total & 282 & 67 & 376 & 360 & 1085 \\
\hline & & \multicolumn{5}{|c|}{ percentage values } \\
\hline & Non trader & 58.5 & 2.0 & 34.8 & 4.7 & 100.0 \\
\hline & Exporter-only & 20.3 & 32.9 & 15.2 & 31.7 & 100.0 \\
\hline & Importer-only & 19.6 & 3.3 & 56.8 & 20.2 & 100.0 \\
\hline & Two-way trader & 7.4 & 6.3 & 19.3 & 67.0 & 100.0 \\
\hline & Total & 26.0 & 6.2 & 34.7 & 33.2 & 100.0 \\
\hline
\end{tabular}

In Table A.2 we provide a description of the variables used in the sample while in Table 4 we show some basic statistics of our sample firms by trade status. The upper panel of the table reports the distribution by size classes, which highlights the well know relationship between trade and size. While approximately $50 \%$ of non-traders have less than 20 employees, the share of exporters and two-way traders is $20.9 \%$ and $11.4 \%$ respectively. Interestingly enough, a rather large share of importers-only has less than 20 employees. This suggests that for firms in the ECA countries, importing intermediate or capital goods is a viable strategy also 
for relatively smaller firms. Exporters are relatively more concentrated among medium-sized firms, while two-way traders are more likely among the larger firms. These patterns are reflected in the average size of firms (lower panel), which is below 100 employees for non-traders and importers, reaches 153 for exporters and 250 for two-way traders. When we compare firms in terms of productivity (which, due to missing information on value added and the stock of capital, can be measured only as sales per worker) we notice that two-way traders are the best performers, while importers-only, despite the relatively smaller size, reach higher productivity level than exporters-only, which in turn have productivity levels not statistically different from non-traders ${ }^{10}$.

Table 4: Descriptive statistics

\begin{tabular}{lcccccc}
\hline & Obs. & $\begin{array}{c}\text { Non } \\
\text { traders }\end{array}$ & $\begin{array}{c}\text { Export } \\
\text {-only }\end{array}$ & $\begin{array}{c}\text { Import } \\
\text {-only }\end{array}$ & $\begin{array}{c}\text { Two-way } \\
\text { traders }\end{array}$ & Total \\
& & \multicolumn{5}{c}{ column percentages } \\
\cline { 3 - 7 } & & 49.65 & 20.9 & 39.1 & 11.39 & 31.52 \\
Small $(<20)$ & 36.88 & 52.24 & 36.44 & 33.61 & 36.59 \\
Medium (20-99) & 13.48 & 26.87 & 24.47 & 55 & 31.89 \\
Large (100 and over) & & 100 & 100 & 100 & 100 & 100 \\
& & \multicolumn{5}{c}{ average values } \\
& 1083 & 69.16 & 153.01 & 87.27 & 250.71 & 140.82 \\
N. employees & 930 & 12.10 & 12.22 & 12.51 & 13.10 & 12.59 \\
Productivity & 1077 & 0.05 & 0.26 & 0.16 & 0.32 & 0.19 \\
Foreign-owned & 1077 & 0.10 & 0.05 & 0.10 & 0.12 & 0.10 \\
State-owned & 1085 & 0.39 & 0.61 & 0.57 & 0.71 & 0.57 \\
Product innovation & 1052 & $29.7 \%$ & $27.4 \%$ & $28.0 \%$ & $29.0 \%$ & $28.8 \%$ \\
WhiteCollar & 1052 &
\end{tabular}

Similar rankings emerge when we investigate other firms' characteristics. In terms of innovation, the unconditional probability to introduce a new product is only $39 \%$ for non-traders, while it is about $60 \%$ for one-way traders, and up to $71 \%$ for two-way traders. The share of white-collar workers also increases moving from one-way to two-way traders, although differences across firm types are not statistically different from zero. Finally, exporters and two-way traders are more likely to be foreign-owned (i.e. affiliates of foreign multinational firms), while exporting is rarer among state-owned companies. In the next section we will use these variables as controls in a bivariate probit regression of the probability to engage in exporting and importing activity.

\footnotetext{
${ }^{10}$ Pairwise t-tests across the 4 possible trade statuses are not shown, but are available from the authors upon request.
} 


\section{Econometric specification and results}

We model the probability of being a trading firm, by specifying a bivariate probit of exporting and importing as a function of previous import and export status, respectively, controlling for country and sector fixed effects, as well as a number of (lagged) firm-level characteristics illustrated in the previous section ${ }^{11}$. This modelling strategy allows to account for the contemporaneous correlation between the two choices and is analogous to the one that Aw, Roberts, and Winston (2007) and Girma, Görg, and Hanley (2008) used to explain the twoway relationship between export and R\&D.

Formally, our empirical model takes the following form:

$$
\exp _{i t}=\left\{\begin{array}{ll}
1 & \text { if } \exp _{i t}^{*}>0 \\
0 & \text { if } \exp _{i t}^{*} \leq 0
\end{array} \quad \text { and } \quad i m p_{i t}= \begin{cases}1 & \text { if } i m p_{i t}^{*}>0 \\
0 & \text { if } i m p_{i t}^{*} \leq 0\end{cases}\right.
$$

with

$$
\left\{\begin{array}{l}
e x p_{i t}^{*}=\delta_{1} i m p_{i, t-3}+\mathbf{x}_{i, t-3}^{\prime} \beta_{1}+\varepsilon_{1 i t} \\
i m p_{i t}^{*}=\delta_{2} \exp _{i, t-3}+\mathbf{x}_{i, t-3}^{\prime} \beta_{2}+\varepsilon_{2 i t}
\end{array}\right.
$$

where the vector of control variables is

$$
\mathbf{x}_{i, t-3}=\left(\text { productivity }_{i, t-3}, \text { size }_{i, t-3}, \text { other }_{\text {controls }}^{i, t-3}, \text { country }_{j}, \text { sector }_{s}\right)
$$

and the the error terms are normally distributed with a zero mean, variance equal to 1 and $\rho$ denoting their covariance term

$$
\left(\begin{array}{l}
\varepsilon_{1 i t} \\
\varepsilon_{2 i t}
\end{array}\right) \sim N\left[\left(\begin{array}{l}
0 \\
0
\end{array}\right),\left(\begin{array}{ll}
1 & \rho \\
\rho & 1
\end{array}\right)\right]
$$

The parameters of the model $\delta_{1}, \delta_{2}, \beta_{1}, \beta_{2}$ and $\rho$ are estimated via maximum likelihood, using Stata 10.1, and presented in Table 5. In specification (1) we present results for the determinants of export (import) controlling for import (export) and country and sector dummies only. Results suggest a two-way relationship between export and import: firms which were involved in importing, after three years are more likely to be exporters and previous exporters are more likely to be importers today. Results are largely confirmed if we control for productivity (column 2), and only a slight drop in the coefficient of past import (export) is registered $^{12}$. More relevant changes are obtained when we control for size, using

\footnotetext{
${ }^{11}$ It is worth recalling that the BEEP surveys are administered every three years, so we are forced to impose a three-year lag in the independent variables.

${ }^{12}$ Due to missing values, the number of observations drops and probably this contributes to increasing the standard errors, making the effect of past exporting on the probability of importing non significantly different from zero at the usual confidence levels.
} 
dummies for small- and medium-sized firms (larger firms being the baseline category): the coefficients on both past export and import status drop but while the latter is still a significant determinant of current exporting activity, the former does not increase the probability of importing. After controlling for firm size and productivity jointly (column 4) and adding other firm characteristics (column 5) the coefficients on past imports and exports drop even more, but the former remains statistically significant ${ }^{13}$.

In sum, the positive two-way correlation between exporting and importing activity in ECA countries is the result of firm-heterogeneity (mainly in term of firm-size) which is correlated with trading activities. To some extent we may think that some of the sunk costs required to export and import are also correlated with firm size and other characteristics (such as being an affiliate of a multinational firm). This is the case for example of an organizational structure which enables the firm to manage international operations. In this perspective, since the two-way correlation between importing and exporting vanishes after controlling for size and other firm characteristics, our results suggest some role for self-selection and common sunk costs. In the following subsections we test for the robustness of our baseline findings. In particular, our first concern is that, for example, there may be persistence in export and import and this, rather than the firm being previously involved in importing (exporting) activities, explains current exporting behavior. In other words, we want to identify the switch from one-way to two-way trader, rather than the persistence in two-way trading. Second, we want to test whether, as suggested by some important contributions in the recent international trade literature, importing intermediates increases firm productivity (Bas and Strauss-Kahn, 2010; Halpern, Koren, and Szeidl, 2009), or product scope and quality (Kugler and Verhoogen, 2009; Goldberg, Khandelwal, Pavcnik, and Topalova, 2010) and through this channel fosters exporting activity. Third, we test whether our results hold in trying to explain the intensive margin of importing and exporting activity.

\footnotetext{
${ }^{13}$ To check whether endogeneity may bias the relationship between past importing status and current exporting behaviour, we consider a recursive probit model (Maddala, 1983). In particular, we estimate the following bivariate probit model for export at time $t$ with the endogenous dummy $i m p_{i, t-3}$ :

$$
\left\{\begin{array}{l}
e x p_{i t}^{*}=\delta_{1} i m p_{i, t-3}+\mathbf{x}_{i, t-3}^{\prime} \beta_{1}+\varepsilon_{1 i t} \\
i m p_{i, t-3}^{*}=\mathbf{x}_{i, t-3}^{\prime} \beta_{2}+\varepsilon_{2 i t}
\end{array}\right.
$$

Results (not presented here, but available from the authors) confirm the existence of a significant positive effect of past importing, while the hypothesis of exogeneity of the lagged import dummy is supported by the absence of statistically significant correlation between the error terms of the two equations (see Monfardini and Radice (2008) for a discussion on testing exogeneity in bivariate probit models).
} 


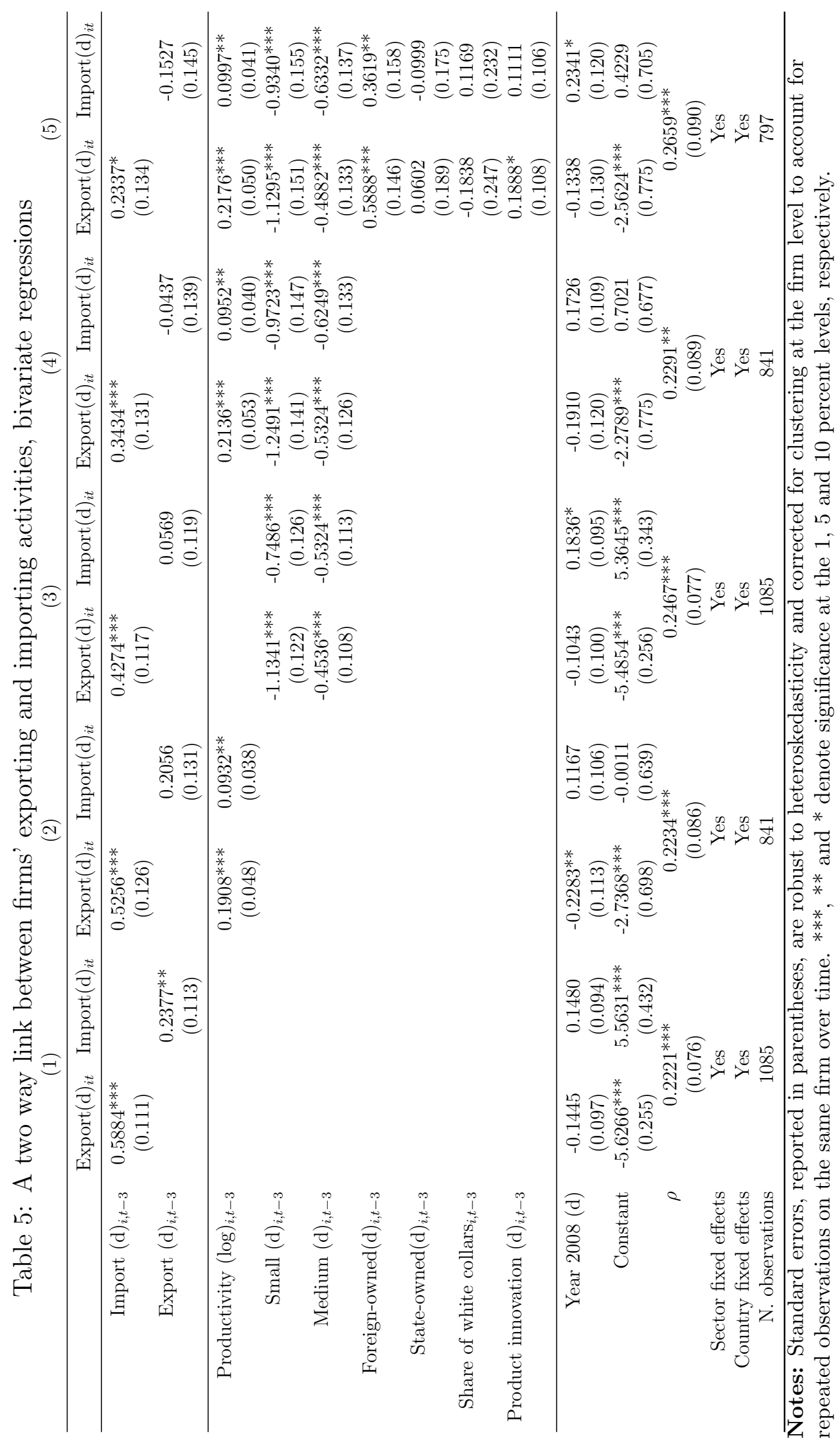




\section{Robustness checks}

\subsection{Lagged dependent variables}

The baseline specification may not be able to capture the true transition from one-way to two-way trading, and may be biased by the fact that previous export (import) status may be correlated with previous import (export) status. Thus, to control for this effect, we introduce the lagged dependent variables. While a proper estimation of such a dynamic model would require to deal with the endogeneity of the lagged dependent variables, our aim here is to show whether and how the baseline results are robust to control for the persistence in trade status $^{14}$. This will allow us to ascertain whether past import (export) has an effect on the probability of exporting (importing) activity conditional on the firms being an exporter (importer) three years earlier. In other words, this will allow to focus on firms switching into export (import) activities.

To fix ideas equation (2) becomes:

$$
\left\{\begin{array}{l}
\exp _{i t}^{*}=\alpha_{1} \exp _{i, t-3}+\delta_{1} i m p_{i, t-3}+\mathbf{x}_{i, t-3}^{\prime} \beta_{1}+\varepsilon_{1 i t} \\
i m p_{i t}^{*}=\alpha_{1} i m p_{i, t-3}+\delta_{2} \exp _{i, t-3}+\mathbf{x}_{i, t-3}^{\prime} \beta_{2}+\varepsilon_{2 i t}
\end{array}\right.
$$

Results, presented in Table 6, suggest that the effect of past import (export) on future export (import) is reduced when we control for the lagged dependent variable. Comparing column 1 in Tables 5 and 6 we gather that the coefficient $\delta_{1}$ drops from 0.588 to 0.473 , while $\delta_{2}$ slides from 0.237 to 0.185 but they both retain statistical significance. Interestingly enough, once controlled for productivity, size and other firm characteristics, the results on $\delta_{1}$ and $\delta_{2}$ from the basic and the dynamic model are remarkably similar, and confirm that being an importer has a positive effect on the probability of becoming a two-way trader, while being an exporter has no such an effect. The main difference between the static and dynamic estimates lies in the coefficient of some of the control variables which reduce in magnitude (as in the case of size dummies) and in some cases become non-significantly different from zero (as for the foreign-owned and product innovation dummy). This is consistent with the fact that these variable are moving slowly over time, and in the dynamic model their effect is thus picked-up by $\alpha_{1}$ and $\alpha_{2}$.

\footnotetext{
${ }^{14}$ Ideally, one would like to control for the intial conditions, using the correction proposed by Wooldridge (2005) and applied to this context by Muûls and Pisu (2009), but in our case, since for most firms we have only two observations this solution is not feasible.
} 


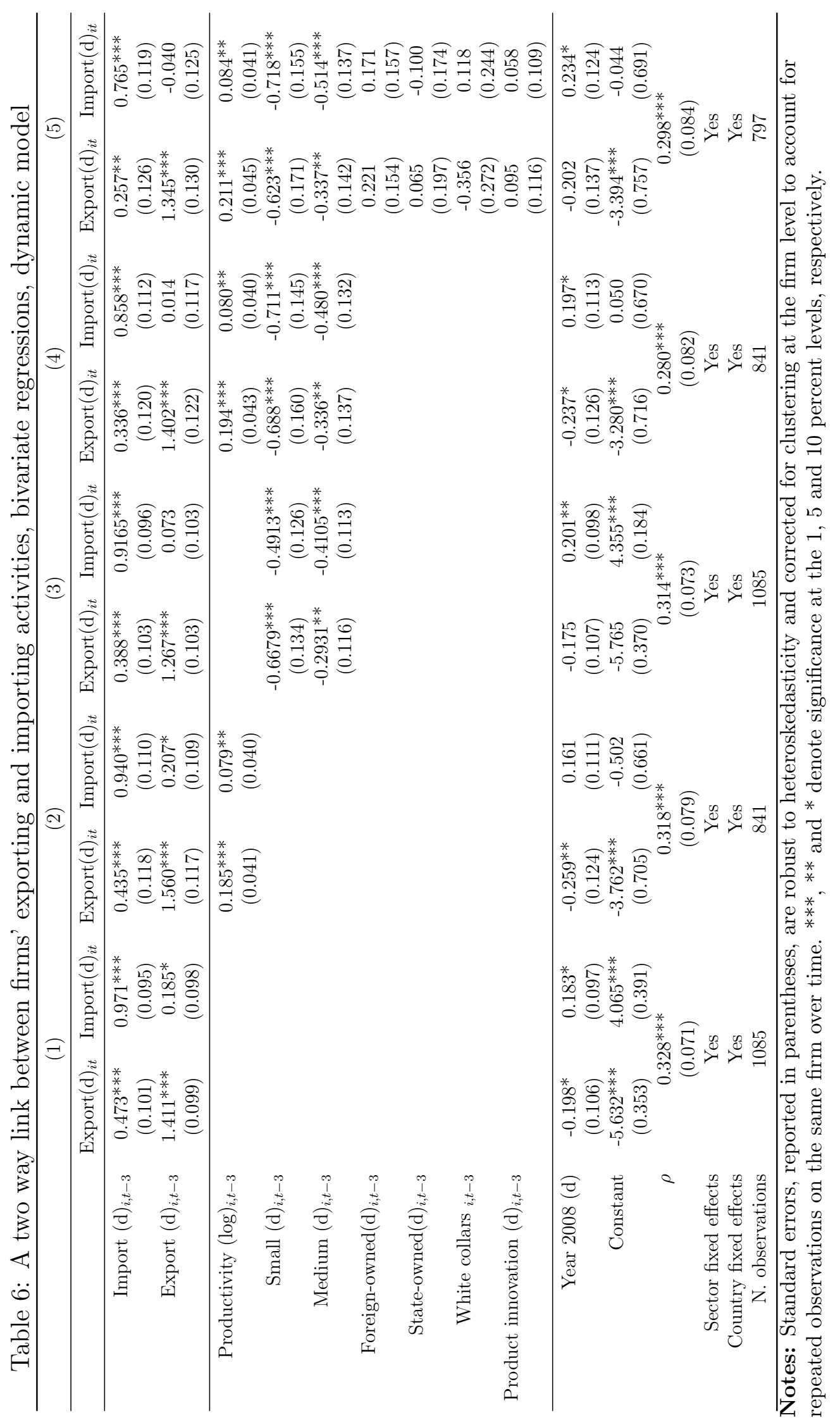




\subsection{Contemporaneous productivity and product innova- tion}

As a further control, we introduce the current level of productivity and propensity to innovate products. Introducing these variables may exacerbate endogeneity problems, but in this way, we are able to shed some light on the channels through which import may affect export. In particular, as emphasized by some previous literature, past import may improve both firm productivity (Amiti and Konings, 2007; Halpern, Koren, and Szeidl, 2009; Kasahara and Rodrigue, 2008) and firm product innovation (Goldberg, Khandelwal, Pavcnik, and Topalova, 2010; Kugler and Verhoogen, 2009), which in turn may foster exporting activity.

We first add either productivity or innovation both at time $t$ and $t-3$ (column 2 and 3 of Table 7). When controlling for current productivity and product innovation, the effect of past import on current export slides and becomes nonsignificantly different from zero. This suggests that past import is correlated with current productivity and product innovation and, once controlled for these variables, the direct effect of past import on current export vanishes. In other other words, these results are consistent with the idea the the effect of import on export is mediated by an increase in productivity and product innovation. Noticeably, the effect through innovation appears more important than the one via productivity increase. In fact, $\delta_{1}$ drops from 0.234 (in column 1 ) to 0.188 (in column 3) upon controlling for product innovation, and slides by a small 0.007 when we further control for productivity (column 4). Conversely, $\delta_{1}$ drops from 0.206 (in column 2) to 0.181 (in column 4) when we add product innovation to the equation controlling for current productivity. Results from the dynamic model, presented in Table 8, are in line with those of the static model. The only difference appears to be that it becomes clearer that product innovation rather than productivity is the more effective channel through which past importing affects current exporting. In fact, while in column (2) $\delta_{1}$ drops only slightly (from 0.257 to 0.244 ) and remain statistically significant, in column (3) it slides from 0.257 to 0.191 and turns non-significantly different from zero.

\subsection{Trade intensity}

In order to further check for the robustness of our results, we turn to the analysis of the intensive margin of firm exporting and importing activity. To this aim, we specify a bivariate Tobit which allows to jointly model the determinants of export and import intensity (measured as the percentage of sales from direct exports and as the percentage of material inputs and supplies of foreign origin, respectively), while controlling for the high proportion of zeros in the two depen- 


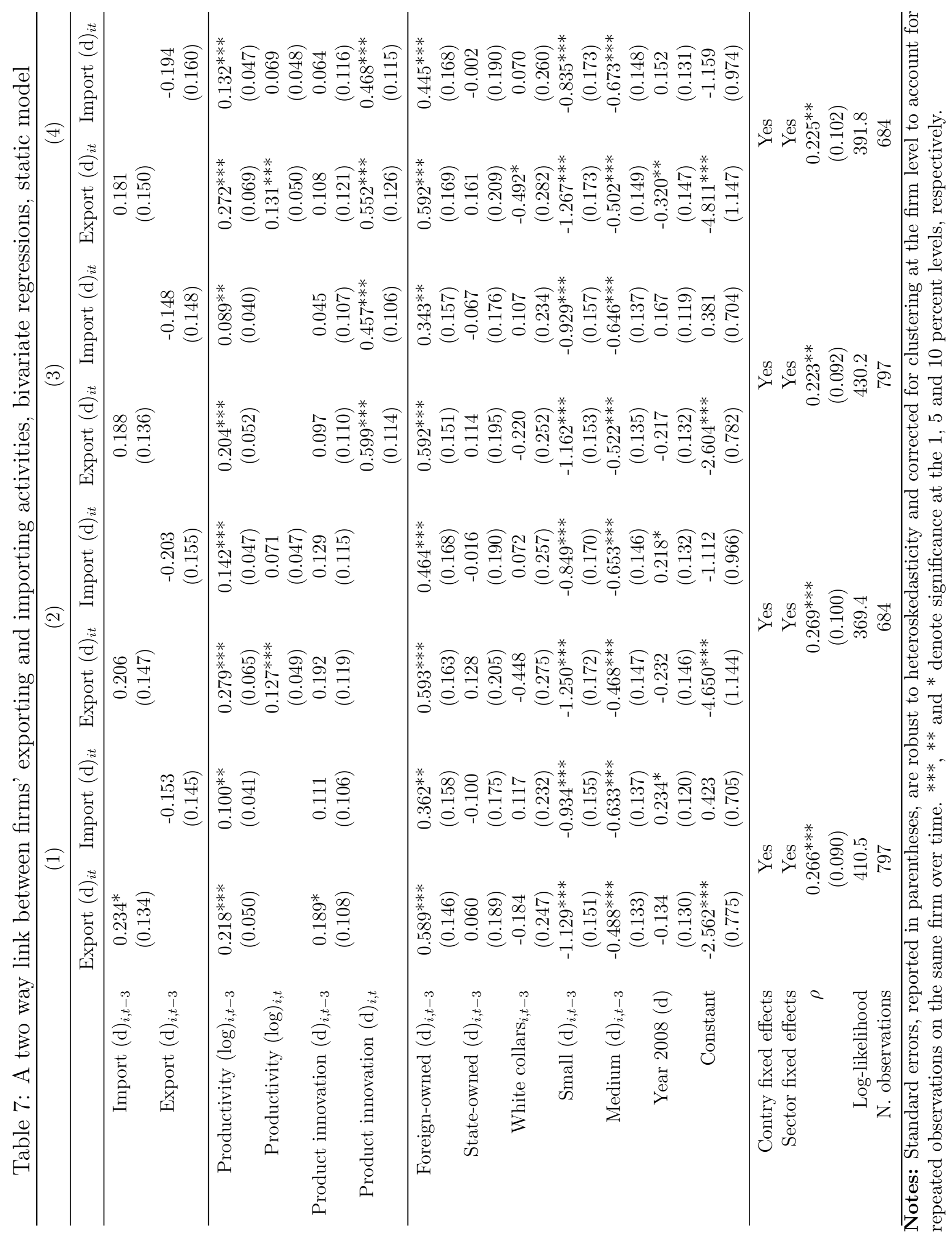




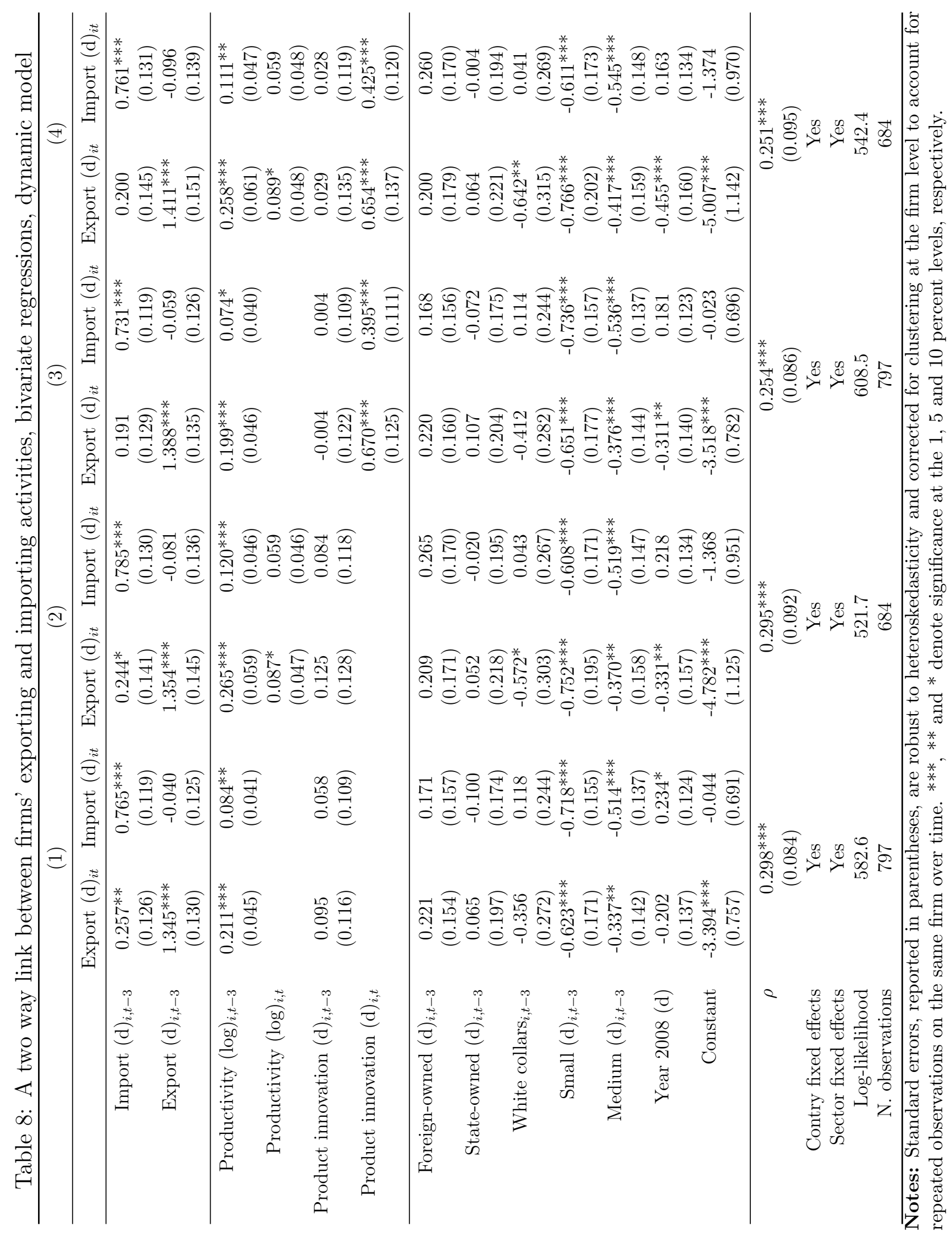


dent variables ${ }^{15}$. In particular, we consider the following bivariate dynamic Tobit model:

$$
\left\{\begin{array}{l}
\text { export_int }_{i t}=\alpha_{1} \text { export_int }_{i, t-3}+\delta_{1} \text { import_int }_{i, t-3}+\mathbf{x}_{i, t-3}^{\prime} \beta_{1}+u_{1 i t} \\
\text { import_int }_{i t}=\alpha_{2} \text { import_int }_{i, t-3}+\delta_{2} \text { export_int }_{i, t-3}+\mathbf{x}_{i, t-3}^{\prime} \beta_{2}+u_{2 i t}
\end{array}\right.
$$

where each equation controls for firm characteristics, for lagged export and import intensities, and the error terms $u_{1}$ and $u_{2}$ are assumed to be normally distribute with zero mean, variances $\sigma_{1}^{2}$ and $\sigma_{2}^{2}$ and covariance equal to $\rho_{12}$ :

$$
\left(\begin{array}{l}
u_{1 i t} \\
u_{2 i t}
\end{array}\right) \sim N\left[\left(\begin{array}{l}
0 \\
0
\end{array}\right),\left(\begin{array}{cc}
\sigma_{2}^{2} & \rho_{12} \\
\rho_{12} & \sigma_{2}^{2}
\end{array}\right)\right]
$$

As previously done for the probit analysis, two alternative specifications of the bivariate dynamic Tobit model have been considered to control also for the effects of contemporaneous productivity levels and innovation activity. Results ${ }^{16}$, presented in Table 9 are in line with the previous ones and suggest that export intensity does not affect firms' importing behaviour, while a higher import intensity foster a higher involvement in international markets. However, as showed in column (2), the effect turns non significantly different from zero once controlling for current productivity and product innovation.

\section{Concluding remarks}

One of the most robust piece of evidence in the recent empirical literature on firm heterogeneity and trade is that a large share of internationalized firms are engaged in both import of intermediate inputs and export of final goods. The co-occurrence of foreign sourcing and exporting at the level of the individual firm raises the question of whether these two activities are actually related. As a matter of fact, this correlation may be the result of self-selection, common sunk costs incurred when exporting and importing, or may depend from the fact that import paves the way to export and/or viceversa. Despite the ample evidence on the empirical relevance of two-way traders, few empirical works have addressed the two-way links between exporting and importing activities at the firm-level.

This paper contributes to this strand of empirical literature by estimating a bivariate probit model of the probability of exporting and importing for a sample of 1,085 firms from 27 ECA countries over the period 2002-2008. We find a correlation between serving foreign markets and sourcing inputs from abroad, but this two-way link disappears after controlling for size, productivity and other firmcharacteristics: while importing remains a positive determinant of the probability

\footnotetext{
${ }^{15}$ In this respect, our approach is close to that of Girma, Görg, and Hanley $(2008)$, who use the 3-stage least squares to estimate the relationships between export and R\&D intensities, but has the advantage of explicitly accounting for the censored nature of the dependent variables.

${ }^{16}$ Estimations have been carried out in Stata 10.1, using the package mvtobit.
} 
Table 9: A two way link between firms' exporting and importing activities, dynamic bivariate tobit model

\begin{tabular}{|c|c|c|c|c|}
\hline & \multicolumn{2}{|c|}{ (1) } & \multicolumn{2}{|c|}{$(2)$} \\
\hline & Export_int $_{i t}$ & Import_int $_{i t}$ & Export_int $_{i t}$ & Import_int $_{i t}$ \\
\hline \multirow{2}{*}{ Import_int $_{i, t-3}$} & 0.089* & $0.548 * * *$ & 0.071 & $0.488 * * *$ \\
\hline & $(0.047)$ & $(0.052)$ & $(0.052)$ & $(0.056)$ \\
\hline \multirow{2}{*}{ Export_int $_{i, t-3}$} & $0.824^{* * *}$ & -0.035 & $0.836^{* * *}$ & -0.023 \\
\hline & $(0.052)$ & $(0.055)$ & $(0.057)$ & $(0.060)$ \\
\hline \multirow{2}{*}{ Productivity $(\log )_{i, t-3}$} & $7.843^{* * *}$ & 0.892 & $8.158^{* * *}$ & 1.564 \\
\hline & $(1.597)$ & $(1.166)$ & $(1.866)$ & $(1.432)$ \\
\hline \multirow{2}{*}{ Productivity $(\log )_{i, t}$} & & & $3.477^{* * * *}$ & 1.605 \\
\hline & & & $(1.254)$ & $(1.314)$ \\
\hline \multirow{2}{*}{ Product innovation $(\mathrm{d})_{i, t-3}$} & $(2.791)$ & 3.189 & $(1.092)$ & -0.655 \\
\hline & $(3.439)$ & $(3.451)$ & $(3.731)$ & $(3.650)$ \\
\hline \multirow[t]{2}{*}{ Product innovation $(\mathrm{d})_{i, t}$} & & & $15.585^{* * *}$ & $15.193^{* * *}$ \\
\hline & & & $(3.907)$ & $(3.945)$ \\
\hline \multirow{2}{*}{ Small $(\mathrm{d})_{i, t-3}$} & $-24.031^{* * *}$ & $-15.406^{* * *}$ & $-22.358 * * *$ & $-12.655^{* *}$ \\
\hline & $(4.887)$ & (4.797) & $(5.349)$ & $(5.126)$ \\
\hline \multirow[t]{2}{*}{$\operatorname{Medium}(\mathrm{d})_{i, t-3}$} & $-10.215^{* *}$ & $-10.809 * * *$ & $-8.339 * *$ & $-10.319^{* *}$ \\
\hline & $(4.053)$ & (4.090) & $(4.164)$ & $(4.366)$ \\
\hline \multirow[t]{2}{*}{ Foreign-owned $(\mathrm{d})_{i, t-3}$} & $8.788^{* *}$ & 3.568 & $(7.723)$ & 5.556 \\
\hline & $(4.476)$ & $(4.588)$ & $(4.776)$ & $(4.867)$ \\
\hline \multirow[t]{2}{*}{ State-owned $(\mathrm{d})_{i, t-3}$} & $(2.479)$ & -3.82 & $(4.520)$ & -2.421 \\
\hline & $(5.212)$ & $(5.892)$ & $(5.248)$ & $(6.372)$ \\
\hline \multirow[t]{2}{*}{ White collars $_{i, t-3}$} & $-(0.435)$ & 7.538 & $-(4.377)$ & 5.34 \\
\hline & $(8.259)$ & $(8.350)$ & $(8.615)$ & $(8.823)$ \\
\hline \multirow[t]{2}{*}{ Year $2008(d)$} & $-10.845^{* * *}$ & 3.51 & $-13.314^{* * *}$ & 1.803 \\
\hline & $(3.860)$ & $(4.157)$ & $(4.217)$ & $(4.474)$ \\
\hline \multirow[t]{2}{*}{ Constant } & $-198.186^{* * *}$ & 8.995 & $-278.481^{* * *}$ & -40.123 \\
\hline & $(41.019)$ & $(30.446)$ & $(52.942)$ & $(42.773)$ \\
\hline \multirow[t]{2}{*}{$\sigma_{1}$} & $35.57 * * *$ & & $34.375^{* * *}$ & \\
\hline & $(1.893)$ & & $(1.970)$ & \\
\hline \multirow[t]{2}{*}{$\sigma_{2}$} & & $42.435^{* * *}$ & & $41.719^{* * *}$ \\
\hline & & $(1.419)$ & & $(1.445)$ \\
\hline \multirow[t]{2}{*}{$\rho_{12}$} & \multicolumn{2}{|c|}{$0.135^{* * *}$} & \multicolumn{2}{|c|}{$0.096^{*}$} \\
\hline & \multicolumn{2}{|c|}{$(0.051)$} & \multicolumn{2}{|c|}{$(0.057)$} \\
\hline \multirow{2}{*}{$\begin{array}{l}\text { LR test of } \rho_{12}=0 \\
\text { p-value }\left(\chi^{2}(1)\right)\end{array}$} & \multicolumn{2}{|c|}{7.41} & \multicolumn{2}{|c|}{3.2} \\
\hline & \multicolumn{2}{|c|}{0.0383} & \multicolumn{2}{|c|}{0.0738} \\
\hline Country fixed effects & & & & es \\
\hline Sector fixed effects & & & & es \\
\hline N. of observations & & & & 68 \\
\hline
\end{tabular}

Notes: Standard errors, reported in parentheses, are robust to heteroskedasticity and corrected for clustering at the firm level to account for repeated observations on the same firm over time. ${ }^{* * *},{ }^{* *}$ and ${ }^{*}$ denote significance at the 1,5 and 10 percent levels, respectively. 
of future exporting activities, serving foreign markets does not seem to affect the probability to source foreign inputs. This result supports the hypothesis that best performing firms self-select as two-way traders, and is partially consistent with the idea there may be some sunk costs complementarity in importing and exporting activities. The positive effect of past importing on current exporting vanishes when we control for current firm productivity and product innovation. This is consistent with the idea that importing intermediate inputs enhances firm productivity and the propensity to introduce new products, which in turn fosters the chances of exporting. In line with some recent works, our paper suggests that falling trade barriers, especially on intermediate inputs, can be an important policy to promote international competitiveness of domestic firms.

Our results are robust to a number of alternative specifications and controls, but it is worth mentioning that the relatively short longitudinal dimension in our data has not allowed us to properly account for the medium-term dynamic interrelationships between exporting and importing activities. To the extent the length of experience in the export market brings about more learning opportunities, one may venture saying that the lack of a longer time series may partly explain the evidence non-significant effects of exporting on the probability of importing. Furthermore, while our analysis has the rare feature of using firm-level information comprable across countries, there may be characteristics common to this set of countries that may partly explain our finding that importing intermediate inputs affects the propensity to export through an increase in product innovation and productivity. In particular, the transition from a centrally planned to a market economy has been accompanied in these countries by a series of institutional reforms and structural changes, among which is trade liberalization and innovation in production technologies, which led to a more intense use of imported inputs, that stimulated economic growth and allowed to increase the quality and variety of exports (Benkovskis and Rimgailaite, 2011; Zaghini, 2005). 


\section{References}

Altomonte, C., And G. Bekes (2010): "Trade Complexity and Productivity," CeFiG Working Papers 12, Center for Firms in the Global Economy.

Alvarez, R., And R. López (2005): "Exporting and performance: evidence from Chilean plants," Canadian Journal of Economics, 38(4), 1384-1400.

Amiti, M., And J. Konings (2007): "Trade Liberalization, Intermediate Inputs, and Productivity: Evidence from Indonesia," American Economic Review, 97(5), 1611-1638.

Andersson, M., And H. Loof (2009): "Learning-by-Exporting Revisited: The Role of Intensity and Persistence," Scandinavian Journal of Economics, 111(4), 893-916.

Andersson, M., H. Loof, and S. Johansson (2008): "Productivity and International Trade: Firm Level Evidence from a Small Open Economy," Review of World Economics, 144 (4), 774-801.

Augier, P., O. Cadot, and M. Dovis (2010): "Imports and TFP at the Firm Level: The Role of Absorptive Capacity," CEPREMAP Working Papers (Docweb) 1016, CEPREMAP.

Aw, B. Y., M. J. Roberts, and T. Winston (2007): "Export Market Participation, Investments in R\&D and Worker Training, and the Evolution of Firm Productivity," The World Economy, 30(1), 83-104.

Awokuse, T. O. (2007): "Causality between exports, imports, and economic growth: Evidence from transition economies," Economics Letters, 94, 389-395.

Bajo-Rubio, O., And C. Díaz-Roldán (2012): "Do exports cause growth? Some evidence for the new EU members," Post-Communist Economies, 24, $125-131$.

BAs, M., And V. Strauss-Kahn (2010): "Does importing more inputs raise exports? Firm level evidence from France," MPRA Paper 27315, University Library of Munich, Germany.

BAsile, R. (2001): "Export behaviour of Italian manufacturing firms over the nineties: the role of innovation," Research Policy, 30, 1185-1201.

Benkovskis, K., and R. Rimgailaite (2011): "The quality and variety of exports from the new EU member states," Economics of Transition, 19 (4).

Bernard, A. B., And B. J. Jensen (1999): "Exceptional exporter performance: cause, effect, or both?," Journal of International Economics, 47(1), $1-25$. 
Bernard, A. B., J. B. Jensen, and P. K. Schott (2009): "Importers, Exporters and Multinationals: A Portrait of Firms in the U.S. that Trade Goods," in Producer Dynamics: New Evidence from Micro Data, NBER Chapters, pp. 513-552. National Bureau of Economic Research, Inc.

Blalock, G., And P. J. Gertler (2004): "Learning from exporting revisited in a less developed setting," Journal of Development Economics, 75(2), 397 416, 15th Inter American Seminar on Economics.

Bratti, M., and G. Felice (2011): "Are Exporters More Likely to Introduce Product Innovations?," Development Working Papers 306, Centro Studi Luca dÁgliano, University of Milano.

Bustos, P. (2011): "Trade Liberalization, Exports, and Technology Upgrading: Evidence on the Impact of MERCOSUR on Argentinian Firms," American Economic Review, 101(1), 304-40.

Caldera, A. (2010): "Innovation and exporting: evidence from Spanish manufacturing firms," Review of World Economics, 146, 657-689.

Cassiman, B., E. Golovko, and E. Martínez-Ros (2010): "Innovation, exports and productivity," International Journal of Industrial Organization, $28,372-376$.

Castellani, D. (2002): "Export behavior and productivity growth: Evidence from Italian manufacturing firms," Review of World Economics (Weltwirtschaftliches Archiv), 138(4), 605-628.

Castellani, D., F. Serti, and C. Tomasi (2010): "Firms in International Trade: Importers' and Exporters' Heterogeneity in Italian Manufacturing Industry," The World Economy, 33(3), 424-457.

Cetintas, H., And S. Barisik (2009): "Export, Import and Economic Growth: The Case of Transition Economies," Transition Studies Review, 15, 636-649.

Clerides, S. K., S. Lach, and J. R. Tybout (1998): "Is Learning By Exporting Important? Micro-Dynamic Evidence ¿From Colombia, Mexico, And Morocco," The Quarterly Journal of Economics, 113(3), 903-947.

Colantone, I., And R. CRinò (2011): "Imported Inputs and Domestic Product Scope," Discussion Paper 312, Centro Studi Luca D'Agliano Working Paper.

Conti, G., A. Lo Turco, and D. Maggioni (2011): "Rethinking the importproducitvity nexus for Italian manufacturing: Do exports matter?," Working paper, Polytechnic University of Marche. 
Damijan, J. P., J. de Sousa, and O. Lamotte (2009): "Does international openness affect the productivity of local firms? Evidence from south-eastern Europe," Economics of Transition, 17(3), 559-586.

Damijan, P. J., and C. Kosteve (2006): "Learning-by-exporting: Continuous productivity improvements or capacity utilization effects? Evidence from Slovenian firms," Review of World Economics, 142, 599-614.

De Loecker, J. (2007): "Do exports generate higher productivity? Evidence from Slovenia," Journal of International Economics, 73(1), 69-98.

Farinas, J. C., And A. Martin-Marcos (2010): "Foreign Sourcing and Productivity: Evidence at the Firm Level," World Economy, 33(3), 482-506.

Forlani, E. (2011): "Irish firms' productivity and imported inputs," mimeo.

Girma, S., H. Görg, And A. Hanley (2008): "R\&D and Exporting: A Comparison of British and Irish Firms," Review of World Economics, 144, 750-773, 10.1007/s10290-008-0168-6.

Girma, S., D. Greenaway, and R. Kneller (2004): "Does Exporting Increase Productivity? A Microeconometric Analysis of Matched Firms," Review of International Economics, 12(5), 855-866.

Goldberg, P. K., A. K. Khandelwal, N. Pavcnik, and P. Topalova (2010): "Imported Intermediate Inputs and Domestic Product Growth: Evidence from India," The Quarterly Journal of Economics, 125(4), 1727-1767.

Halpern, L., M. Koren, And A. Szeidl (2009): "Imported Inputs and Productivity," CeFiG Working Papers 8, Center for Firms in the Global Economy.

ISGEP (2008): "Understanding Cross-Country Differences in Exporter Premia: Comparable Evidence for 14 Countries," Review of World Economics, 144, 596-635, The International Study Group on Export and Productivity.

Kasahara, H., and B. Lapham (2008): "Productivity and the Decision to Import and Export: Theory and Evidence," Discussion Paper 2240, Cesifo Working Paper.

Kasahara, H., And J. Rodrigue (2008): "Does the use of imported intermediates increase productivity? Plant-level evidence," Journal of Development Economics, 87(1), 106-118.

KrAAY, A. (1999): "Exports and economic performance: evidence from a panel of Chinese enterprises," Revue d'Economie du Developpement, (1-2), 183-207. 
Kugler, M., and E. Verhoogen (2009): "Plants and Imported Inputs: New Facts and an Interpretation," American Economic Review, 99(2), 501-07.

Lileeva, A., And D. Trefler (2010): "Improved Access to Foreign Markets Raises Plant-Level Productivity... for Some Plants," The Quarterly Journal of Economics, 125(3), 1051-1099.

Lo Turco, A., And D. Maggioni (2011): "The role of imports in enhancing manufacturing exports," Discussion paper, Department of Economics, Polytechnic University of Marche.

Loof, H., And M. Andersson (2010): "Imports, Productivity and Origin Markets: The Role of Knowledge-intensive Economies," World Economy, 33(3), 458-481.

Maddala, G. S. (1983): Limited Dependent and Qualitative Variables in Econometrics. Cambridge University Press, Cambridge.

Melitz, M. J. (2003): "The Impact of Trade on Intra-Industry Reallocations and Aggregate Industry Productivity," Econometrica, 71(6), 1695-1725.

Monfardini, C., and R. Radice (2008): "Testing exogeneity in the bivariate Probit model: A Monte Carlo study," Oxford Bulletin of Economics and Statistics, 70 (2), 271-282.

Mû̂ls, M., AND M. Pisu (2009): "Imports and Exports at the Level of the Firm: Evidence from Belgium," The World Economy, 32(5), 692-734.

Park, A., D. Yang, X. Shi, and Y. Jiang (2010): "Exporting and Firm Performance: Chinese Exporters and the Asian Financial Crisis," Review of Economics and Statistics, 92(4), 822-842.

RoPer, S., AND J. LOVE (2002): "Innovation and export performance: evidence from the UK and German manufacturing plants," Research Policy, 31, 10871102 .

Salomon, R. M., And J. M. Shaver (2005): "Learning by Exporting: New Insights from Examining Firm Innovation," Journal of Economics 83 Management Strategy, 14(2), 431-460.

SEKER, M. (2009): "Importing, exporting and innovation in developing countries," Policy Research Working Paper Series 5156, The World Bank.

Serti, F., And C. Tomasi (2008): "Self-Selection and Post-Entry Effects of Exports: Evidence from Italian Manufacturing Firms," Review of World Economics, 144, 660-694, 10.1007/s10290-008-0165-9. 
Smeets, V., And F. WARzynski (2010): "Learning by Exporting, Importing or Both? Estimating productivity with multi-product firms, pricing heterogeneity and the role of international trade," Working Papers 10-13, University of Aarhus, Aarhus School of Business, Department of Economics.

Sterlacchini, A. (1999): "Do innovative activities matter to small firms in nonR\&D-intensive industries? An application to export performance," Research Policy, pp. 819-832.

VAN Biesebroeck, J. (2005): "Exporting raises productivity in sub-Saharan African manufacturing firms," Journal of International Economics, 67(2), 373391.

Verhoogen, E. A. (2008): "Trade, Quality Upgrading, and Wage Inequality in the Mexican Manufacturing Sector," The Quarterly Journal of Economics, $123(2), 489-530$.

Vogel, A., AND J. Wagner (2010): "Higher productivity in importing German manufacturing firms: self-selection, learning from importing, or both?," Review of World Economics, 145, 641-665, 10.1007/s10290-009-0031-4.

Wagner, J. (2007): "Exports and Productivity: A Survey of the Evidence from Firm-level Data," The World Economy, 30(1), 60-82.

Wilhelmsson, F., AND K. Kozlov (2007): "Exports and productivity of Russian firms: in search of causality," Economic Change and Restructuring, 40, $361-385$.

Wooldridge, J. M. (2005): "Simple Solutions to the Initial Conditions Problem in Dynamic, Nonlinear Panel Data Models with Unobserved Heterogeneity," Journal of Applied Econometrics, 20(39-54).

ZaGhini, A. (2005): "Evolution of trade patterns in the new EU member states," Economics of Transition, 13(4). 


\section{Appendix}

Table A.1: Sample composition by country

\begin{tabular}{|c|c|c|c|}
\hline \multirow[b]{2}{*}{ Country } & \multirow[b]{2}{*}{ Estimation sample } & \multicolumn{2}{|c|}{ World Bank's Original datasets (2002-2008) } \\
\hline & & Pooled cross-sections & Longitudinal component \\
\hline Albania & 3.04 & 1.55 & 3.00 \\
\hline Belarus & 2.67 & 2.07 & 2.63 \\
\hline Georgia & 2.86 & 2.27 & 2.77 \\
\hline Tajikistan & 3.04 & 2.33 & 3.19 \\
\hline Ukraine & 8.29 & 10.12 & 8.06 \\
\hline Uzbekistan & 4.15 & 2.58 & 3.98 \\
\hline Russia & 2.03 & 10.90 & 2.20 \\
\hline Poland & 4.06 & 8.71 & 4.36 \\
\hline Romania & 6.82 & 7.40 & 7.88 \\
\hline Serbia & 5.53 & 2.98 & 5.25 \\
\hline Kazakhstan & 4.70 & 6.96 & 4.74 \\
\hline Moldova & 6.91 & 3.91 & 6.80 \\
\hline Bosnia & 2.40 & 2.57 & 2.63 \\
\hline Azerbaijan & 6.45 & 4.19 & 6.09 \\
\hline FYROM & 4.06 & 2.38 & 3.94 \\
\hline Armenia & 6.18 & 4.45 & 6.05 \\
\hline Kyrgyz & 3.41 & 2.19 & 3.33 \\
\hline Estonia & 1.94 & 1.75 & 1.88 \\
\hline Czech Republic & 1.47 & 2.53 & 1.50 \\
\hline Hungary & 2.95 & 6.14 & 2.81 \\
\hline Latvia & 2.21 & 1.67 & 2.25 \\
\hline Lithuania & 2.21 & 2.08 & 2.30 \\
\hline Slovakia & 1.57 & 1.69 & 1.69 \\
\hline Slovenia & 3.78 & 2.22 & 3.61 \\
\hline Bulgaria & 4.24 & 2.22 & 3.94 \\
\hline Croatia & 2.86 & 1.62 & 2.86 \\
\hline Montenegro & 0.18 & 0.51 & 0.28 \\
\hline Total & 100.00 & 100.00 & 100.00 \\
\hline (N. of obs) & 1,085 & 7,979 & 2,133 \\
\hline
\end{tabular}

Source: BEEPS Panel dataset 2002-2008 (version as of April 30, 2010). Data refer to manufacturing firms from all the ECA countries surveyed in BEEPS, except Turkey. 
Table A.2: Variable definitions

\begin{tabular}{|c|c|}
\hline Variable & Description \\
\hline \multicolumn{2}{|c|}{ Dependent variables } \\
\hline Export & $\begin{array}{l}\text { Equals } 1 \text { if firm directly exports its products and services; } 0 \\
\text { otherwise }\end{array}$ \\
\hline Import & $\begin{array}{l}\text { Equals } 1 \text { if firm uses material inputs and supplies of foreign } \\
\text { origin; } 0 \text { otherwise }\end{array}$ \\
\hline Export_int & Share of firm sales deriving from direct exports \\
\hline Import_int & Share of material inputs and supplies of foreign origin \\
\hline \multicolumn{2}{|c|}{ Explanatory variables (Continuous) } \\
\hline Productivity & Sales per worker (in logs) \\
\hline White collar & Percentage of non-production workers \\
\hline \multicolumn{2}{|c|}{ Explanatory variables (Binary) } \\
\hline Product Innovation & $\begin{array}{l}\text { Dummy variable equal to } 1 \text { if firm has introduced new prod- } \\
\text { ucts or services in the last three fiscal years; } 0 \text { otherwise }\end{array}$ \\
\hline Small & Equals 1 if firm has less than 20 employees; 0 otherwise \\
\hline Medium & Equals 1 if firm has 20 to 99 employees; 0 otherwise \\
\hline Foreign-owned & Equals 1 if firm is foreign-owned; 0 otherwise \\
\hline State-owned & Equals 1 if firm is state-owned; 0 otherwise \\
\hline
\end{tabular}


Table A.3: Descriptive statistics: estimation sample and original data

\begin{tabular}{|c|c|c|c|c|}
\hline & & & \multicolumn{2}{|c|}{ World Bank's Original datasets (2002-2008) } \\
\hline Variables & Sample Statistics & Estimation sample & Pooled cross-sections & Longitudinal component \\
\hline \multirow[t]{3}{*}{ Export } & Mean & 0.394 & 0.340 & 0.400 \\
\hline & Std. Dev. & 0.489 & 0.474 & 0.490 \\
\hline & $\mathrm{N}$ & 1085 & 7978 & 2133 \\
\hline \multirow[t]{3}{*}{ Import } & Mean & 0.678 & 0.610 & 0.663 \\
\hline & Std. Dev. & 0.467 & 0.488 & 0.473 \\
\hline & $\mathrm{N}$ & 1085 & 7807 & 2095 \\
\hline \multirow[t]{3}{*}{ Export_int } & Mean & 17.286 & 14.782 & 17.564 \\
\hline & Std. Dev. & 30.328 & 28.708 & 30.388 \\
\hline & $\mathrm{N}$ & 1085 & 7978 & 2133 \\
\hline \multirow[t]{3}{*}{ Import_int } & Mean & 39.694 & 33.281 & 39.261 \\
\hline & Std. Dev. & 38.975 & 37.772 & 38.839 \\
\hline & $\mathrm{N}$ & 1051 & 7434 & 2048 \\
\hline \multirow[t]{3}{*}{ Productivity } & Mean & 12.593 & 12.601 & 12.610 \\
\hline & Std. Dev. & 2.575 & 2.620 & 2.916 \\
\hline & $\mathrm{N}$ & 930 & 6241 & 1736 \\
\hline \multirow[t]{3}{*}{ Small } & Mean & 0.315 & 0.356 & 0.330 \\
\hline & Std. Dev. & 0.465 & 0.479 & 0.470 \\
\hline & $\mathrm{N}$ & 1085 & 7977 & 2132 \\
\hline \multirow[t]{3}{*}{ Medium } & Mean & 0.366 & 0.353 & 0.359 \\
\hline & Std. Dev. & 0.482 & 0.478 & 0.480 \\
\hline & $\mathrm{N}$ & 1085 & 7977 & 2132 \\
\hline \multirow[t]{3}{*}{ Large } & Mean & 0.319 & 0.291 & 0.311 \\
\hline & Std. Dev. & 0.466 & 0.454 & 0.463 \\
\hline & $\mathrm{N}$ & 1085 & 7977 & 2132 \\
\hline \multirow[t]{3}{*}{ Foreign-owned } & Mean & 0.192 & 0.146 & 0.193 \\
\hline & Std. Dev. & 0.394 & 0.353 & 0.395 \\
\hline & $\mathrm{N}$ & 1077 & 7883 & 2079 \\
\hline \multirow[t]{3}{*}{ State-owned } & Mean & 0.102 & 0.072 & 0.117 \\
\hline & Std. Dev. & 0.303 & 0.258 & 0.321 \\
\hline & $\mathrm{N}$ & 1077 & 7886 & 2082 \\
\hline \multirow[t]{3}{*}{ WhiteCollar } & Mean & 0.288 & 0.291 & 0.310 \\
\hline & Std. Dev. & 0.194 & 0.208 & 0.218 \\
\hline & $\mathrm{N}$ & 1052 & 7547 & 2087 \\
\hline \multirow[t]{3}{*}{ Innovation } & Mean & 0.571 & 0.529 & 0.544 \\
\hline & Std. Dev. & 0.495 & 0.499 & 0.498 \\
\hline & $\mathrm{N}$ & 1085 & 7962 & 2130 \\
\hline
\end{tabular}

Source: BEEPS Panel dataset 2002-2008 (version as of April 30, 2010). Data refer to manufacturing firms from all the ECA countries surveyed in BEEPS, except Turkey. 